\title{
Effect of exercise training on long-term weight maintenance in weight-reduced men.
}

Citation for published version (APA):

Pasman, W. J., Saris, W. H. M., Muls, E., Vansant, G., \& Westerterp-Plantenga, M. S. (1999). Effect of exercise training on long-term weight maintenance in weight-reduced men. Metabolism-Clinical and Experimental, 48(1), 15-21. https://doi.org/10.1016/S0026-0495(99)90004-5

Document status and date:

Published: 01/01/1999

DOI:

10.1016/S0026-0495(99)90004-5

Document Version:

Publisher's PDF, also known as Version of record

\section{Please check the document version of this publication:}

- A submitted manuscript is the version of the article upon submission and before peer-review. There can be important differences between the submitted version and the official published version of record.

People interested in the research are advised to contact the author for the final version of the publication, or visit the DOI to the publisher's website.

- The final author version and the galley proof are versions of the publication after peer review.

- The final published version features the final layout of the paper including the volume, issue and page numbers.

Link to publication

\footnotetext{
General rights rights.

- You may freely distribute the URL identifying the publication in the public portal. please follow below link for the End User Agreement:

www.umlib.nl/taverne-license

Take down policy

If you believe that this document breaches copyright please contact us at:

repository@maastrichtuniversity.nl

providing details and we will investigate your claim.
}

Copyright and moral rights for the publications made accessible in the public portal are retained by the authors and/or other copyright owners and it is a condition of accessing publications that users recognise and abide by the legal requirements associated with these

- Users may download and print one copy of any publication from the public portal for the purpose of private study or research.

- You may not further distribute the material or use it for any profit-making activity or commercial gain

If the publication is distributed under the terms of Article $25 \mathrm{fa}$ of the Dutch Copyright Act, indicated by the "Taverne" license above, 


\title{
Effect of Exercise Training on Long-Term Weight Maintenance in Weight-Reduced Men
}

\author{
Wilrike J. Pasman, Wim H.M. Saris, Erik Muls, Greet Vansant, and Margriet S. Westerterp-Plantenga
}

\begin{abstract}
This study investigated whether endurance training is effective for successful long-term weight maintenance after weight reduction. Fifteen male obese subjects (age, $37.3 \pm 5.2$ years; body weight [BW], $96.2 \pm 13.6 \mathrm{~kg}$; body mass index [BMI], $30.9 \pm 2.8 \mathrm{~kg} \cdot \mathrm{m}^{-2}$ / participated in a 16-month exercise-intervention study. During the first 4 months, all subjects trained three to four times weekly, consuming a very-low-energy diet (VLED) during the first 2 months. After the 4-month treatment period, seven subjects continued training for 12 months ( 3 to 4 times per week). The other eight subjects served as a control group not involved in a training program. The regain (increase during the intervention period as a percentage of the 4-month treatment) of BW at 16 months was $64 \%( \pm 26 \%)$ for the whole group (trained $v$ control, $52 \% \pm 28 \% v 74 \% \pm 20 \%, P=.09$ ). The increase in absolute fat mass (FM) was significantly lower at 16 months for the trained group (trained v control, $4.8 \pm 1.9 \mathrm{v9.0} \pm 3.3 \mathrm{~kg}$ ), as was the regain of FM at 16 months (trained $v$ control, $61 \% \pm 24 \% v 92 \% \pm 32 \%, P=.05$ ). The amount of regain of the waist circumference, waist to hip ratio (WHR), and sagittal diameter were correlated with the amount of training (hours) performed weekly ( $\Delta$ waist, $r=-.55, P<.05 ; \Delta W H R, r=-.50, P=.06 ; \Delta$ sagittal diameter, $r=-.53, P<.05$ ). Physical fitness parameters (maximal power output [Wmax] and oxygen uptake $\left[\dot{\mathrm{V}}_{2}\right.$ max]) were significantly increased in both groups at 4 months. Trained subjects maintained high levels of physical fitness at 16 months, in contrast to the control group. In conclusion, although BW regain was not significantly different between the groups, trained subjects showed less regain of FM and higher levels of physical fitness, factors related to a lower risk for cardiovascular disease (CVD), compared with the control group. Furthermore, the regain of FM, which occurred even in the exercising group with a relatively intensive training program, suggests that maintenance of fat loss is extremely difficult.
\end{abstract}

Copyright $\odot 1999$ by W.B. Saunders Company

O BESITY, defined as a body mass index (BMI) greater than $30 \mathrm{~kg} \cdot \mathrm{m}^{-2}$, is known to be related to an increased risk for cardiovascular disease (CVD), hypertension, and diabetes mellitus. ${ }^{1-3}$ The prevalence of obesity has increased in the United States, ${ }^{4}$ as well as Europe. ${ }^{5}$ Weight loss intervention programs are usually successful; however, results with respect to long-term weight maintenance are disappointing. ${ }^{6-8}$

Obesity is caused by chronic positive energy balance, which in turn is mainly caused by a positive lipid balance. ${ }^{9}$ To accomplish weight reduction by a negative fat balance, obese subjects should limit fat intake and/or increase fat oxidation. ${ }^{10}$ Increased fat oxidation may be accomplished by exercise training. Bouchard et al ${ }^{11}$ suggest that obese subjects should have an exercise prescription that results in long-term negative energy balance. This would be the case if endurance exercise of moderate intensity, of long duration, and preferably performed on a daily basis takes place. ${ }^{11,12}$ Another beneficial effect of this type of exercise is the reduction of risk factors for CVD known to be related to obesity. ${ }^{11,13,14}$

Buemann and Tremblay ${ }^{15}$ reviewed the use of physical training as a nonpharmacological tool in the treatment of abdominal obesity and associated metabolic diseases..$^{15}$ With endurance training, obese males show a loss of visceral fat. ${ }^{10}$ It is known that obesity, and upper-body obesity in particular, is related to increased cardiovascular risk factors like insulin resistance, hypertension, and elevated plasma low-density lipoprotein (LDL) levels. ${ }^{14-16}$ Moreover, inactivity has been found to be correlated with an increased risk of CVD. ${ }^{17}$ The amount of physical activity is further known to be dependent on cultural differences; Kushner et al $^{18}$ reported lower physical activity in black women compared with white women, which might have consequences for the prevalence of obesity and CVD in these groups. Therefore, regular endurance exercise may not only increase fat oxidation but also induce positive changes with respect to decreasing the risk factors for CVD. ${ }^{11,12,15}$

Based on the aforementioned poor success rates for long- term weight maintenance we hypothesized that subjects with recent weight loss are the most vulnerable to regaining weight and the best subjects for investigation of long-term intervention strategies for weight maintenance. Therefore, it is hypothesized in the present study that regular endurance exercise would be beneficial for long-term weight maintenance in weight-reduced subjects and to decrease the risk factors for CVD. Since it is known that adherence to an exercise program may be important for long-term weight maintenance, ${ }^{19}$ compliance to the study protocol is crucial in these types of studies.

\section{SUBJECTS AND METHODS}

\section{Subjects}

Sixteen male obese subjects recruited by advertisement in a local newspaper, participated in the study (age, $37.3 \pm 5.2$ years; body weight [BW], $96.5 \pm 13.6 \mathrm{~kg}$; BMI, $30.9 \pm 2.8 \mathrm{~kg} \cdot \mathrm{m}^{-2}$ ). The verylow-energy diet (VLED) was started with 16 male obese subjects: 15 completed the VLED period and one was not able to adhere to the strict diet regimen and was therefore excluded from the protocol. Written informed consent was obtained from each subject at the start of the study. The study protocol was reviewed and approved by the Medical Committee of Maastricht University.

\section{Study Design}

All subjects took part in an endurance training program during the first 4 months of the study, which also included a VLED period of 2

From the Department of Human Biology, Maastricht University, Maastricht; Open University, Heerlen, The Netherlands; and the Departments of Endocrinology, Metabolism and Nutrition and Clinical Chemistry, University Hospital Gasthuisberg, Leuven, Belgium.

Submitted June 28, 1997; accepted May 13, 1998.

Address reprint requests to Wilrike J. Pasman, PhD, Maastricht University, Department of Human Biology, PO Box 616, 6200 MD Maastricht, The Netherlands.

Copyright (C 1999 by W.B. Saunders Company

0026-0495/99/4801-0004\$03.00/0 
months, to lose weight. The VLED provided 2 MJ daily and was a protein-enriched formula diet (Modifast; Novartis Nutrition, Bern, Switzerland: $44 \%$ protein, $14 \%$ fat, and $42 \%$ carbohydrate as a percentage of energy). The diet provided $55 \mathrm{~g}$ protein daily. The vitamins and minerals added to the diet meet the recommended daily allowance when three sachets per day were consumed as prescribed. The VLED was dissolved with water to make a milkshake or dessert. After 2 months, food intake was ad libitum, but advice was given about healthy food consumption. All subjects took part in the endurance training program during the first 4 months of the study to prevent a fast BW rebound after the VLED and to have a nonsignificantly different starting point to study weight maintenance. They ran and cycled at moderate intensity for at least 1 hour three to four times per week and were professionally coached. After 4 months, seven subjects continued the training sessions for 12 months at a triathlon club, where they were able to swim, cycle, and run in group sessions (three to four times per week) supervised by a coach (trained group). After 4 months, randomization was scheduled based on age, BMI, and weight loss. However, three subjects were not willing to continue the training program. We therefore ended up with a control group of eight subjects not involved in a training program. Physical characteristics of the trained group and control group were not significantly different at 4 months. The study design is presented in Fig 1.

\section{Compliance to Endurance Training During the Weight-Maintenance Phase}

Compliance to the training sessions and daily physical activity in general was monitored in multiple ways. For the trained group, a training diary was used for day-to-day activities and remarks (illness, injury, weather conditions, etc.). The investigator visited training sessions of the triathlon club frequently to examine compliance during the 12-month follow-up period. Compliance to the prescribed training sessions was $89 \% \pm 26 \%$ for the trained group in the intervention period. Besides the training diaries, questionnaires were completed at the laboratory when measurements took place to check daily physical activity by all subjects.

\section{Measurement Protocol}

After an overnight fast, subjects came to the laboratory at $0,2,4,10$, and 16 months at $8 \mathrm{AM}$ for different measurements.

Resting metabolic rate. The resting metabolic rate (RMR) was measured for 45 minutes at $8 \mathrm{AM}$. Subjects arrived at the laboratory by car or public transportation to minimize physical activity. Oxygen consumption and carbon dioxide production were measured by an open-circuit ventilated-hood system (Human Biology, Maastricht, Uni-

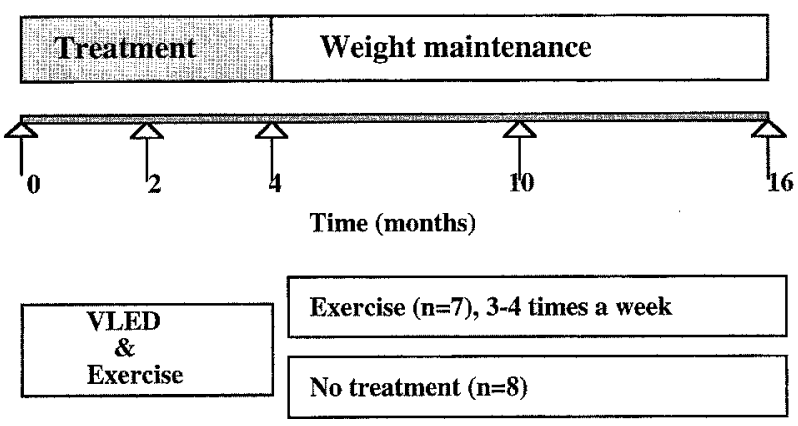

Fig 1. Study design of the long-term exercise intervention study. All subjects participated in a training program during the first 4 months ( 3 to 4 times weekly), the first 2 months of which they were on a VLED. After 4 months, only 1 group continued the exercise training. Measurements were made at $0,2,4,10$, and 16 months as indicated by arrows. versity Maastricht, The Netherlands). Measurement of energy expenditure was based on the Weir formulas. ${ }^{20}$

Blood analysis. On all test days, blood samples were obtained from the subjects and blood pressure was measured. Blood plasma was mixed with EDTA to prevent clotting and immediately centrifuged. Serum was obtained by centrifugation of blood after 1 hour at room temperature. Plasma and serum samples were stored at $-80^{\circ} \mathrm{C}$ until further analysis. Total cholesterol, LDL and high-density lipoprotein (HDL) cholesterol, triglycerides, and apolipoprotein Al (apo A1) and apo B were determined as described by Muls et al. ${ }^{21}$

Anthropometry. Subjects were weighed on a digital balance accurate to $0.1 \mathrm{~kg}$ (D-7470; Sauter, Ebingen, Germany). Height was obtained to the nearest $0.1 \mathrm{~cm}$ using a wall-mounted stadiometer (model 220; Seca, Hamburg, Germany). The BMI was calculated as BW in kilograms divided by height in meters squared. Fat distribution was investigated by measuring the waist and hip circumference and calculating the waist to hip ratio (WHR) and sagittal diameter. The waist circumference was measured at the smallest circumference between the rib cage and the iliac crest with the subject standing. The hip circumference was measured at the widest circumference between the waist and the thighs. The WHR was calculated by dividing the waist circumference by the hip circumference. For determination of the sagittal diameter, the distance between the abdomen and the back, a stadiometer was used with the subject in the supine position.

The deuterium dilution technique was used for measurement of body composition. ${ }^{22}{ }^{2} \mathrm{H}_{2} \mathrm{O}$ dilution was used to measure total body water (TBW). Subjects were asked to collect a urine sample in the evening just before drinking the deuterium-enriched water solution. After ingestion of this solution, no further consumption was allowed. Ten hours after drinking the water solution, another urine sample was collected. The dilution of the deuterium isotope is a measure of the TBW of the subject. ${ }^{23}$ Deuterium was measured in the urine samples with an isotope ratio mass spectrometer (VG-Isogas Aqua Sira, VG Isogas, Middlewich, Cheshire, England). TBW was obtained by dividing the measured deuterium dilution space by 1.04 .22 Fat-free mass (FFM) was calculated by dividing TBW by the hydration factor 0.73 .

Physical fitness. To investigate the effect of the training program on performance capacity (maximal oxygen uptake $\left[\dot{\mathrm{V}} \mathrm{O}_{2} \max \right]$ ) and maximal power output (Wmax), an incremental exercise test was performed on an electromagnetically braked cycle ergometer (Lode, Groningen, The Netherlands). After a warm-up period of 9 minutes ( 5 minutes at $40 \mathrm{~W}$ and 4 minutes at $80 \mathrm{~W}$ ), the workload was increased every minute by $20 \mathrm{~W}$ until exhaustion. Wmax was calculated using the total time cycled in the exercise test. The highest workload completed for 1 minute (Wcompleted) and the number of seconds (X) the final increase of $20 \mathrm{~W}$ was maintained were added according to the following formula: Wmax $=$ Wcompleted $+([\mathrm{X} / 60] \cdot 20)$. The criteria for maximal performance were forced ventilation, a plateau in oxygen uptake, or a respiratory exchange ratio greater than 1.1. Oxygen uptake during the test was measured continuously using a computerized open system (Oxycon Beta; Mijnhardt, Bunnik, The Netherlands).

\section{Statistics}

A two-way ANOVA with repeated measurements was used to compare variables across groups and over time. When ANOVA testing revealed significant differences over time, post hoc tests were performed with a one-way ANOVA (factor time) to examine which time points differed. Differences between groups were tested post hoc with unpaired $t$ tests. Data are presented as the mean \pm SD. Changes in the parameters measured are expressed as a percentage of the baseline value. Pearson correlations were calculated between the number of training hours and regain of BW, regain of FM, waist circumference, sagittal diameter, Wmax, and $\mathrm{VO}_{2} \max$. For all statistics, the two-tailed significance level was set at $P$ less than .05 . 


\section{RESULTS}

Baseline characteristics of the subjects are shown in Table 1. No significant differences were found between the groups for physical characteristics before the study. At 4 months, with formation of the two groups, physical characteristics were even more similar. The BW at 4 months was $82.0 \pm 10.8 \mathrm{~kg}$ for the trained subjects versus $85.6 \pm 13.8 \mathrm{~kg}$ for the controls $(P=.58)$. The BMI was $26.3 \pm 2.2 \mathrm{~kg} \cdot \mathrm{m}^{-2}$ for trained subjects versus $27.3 \pm 2.2 \mathrm{~kg} \cdot \mathrm{m}^{-2}$ for the controls $(P=.39)$. The sagittal diameter was $18.1 \pm 1.5 \mathrm{~cm}$ at 4 months for trained subjects and $18.9 \pm 1.9 \mathrm{~cm}$ for the controls $(P=.40)$. The body fat percentage also was not significantly different at 4 months $(21.8 \% \pm 3.8 \%$ for trained $v 24.1 \% \pm 4.2 \%$ for control, $P=.31)$.

\section{$B W$ and $F M$ Changes}

Changes in relative BW (expressed as a percentage of the baseline value) are presented in Fig 2 for the trained and control groups. No differences were found between the two groups over the whole study period with respect to absolute or relative BW. Over time, significant changes were found in relative BW for both groups. The amount of $\mathrm{BW}$ lost during the 4-month treatment period was not significantly different between both groups: trained subjects lost $11.1 \pm 4.5 \mathrm{~kg}$ and the control group lost $13.9 \pm 2.8 \mathrm{~kg}(P=.17)$. The relative $\mathrm{BW}$ at 16 months $(94.0 \% \pm 3.6 \%$ for trained $v 96.0 \% \pm 3.0 \%$ for control, $P=.25)$ was still significantly lower for both groups versus the beginning of the study (Fig 2). When the amount of BW lost during the 4-month treatment period was set at $100 \%$ and the regain of $\mathrm{BW}$ during the 12-month follow-up period was expressed as a percentage of the treatment loss, three subjects in the trained group regained less than $50 \%$ at 16 months versus one subject in the control group. Seven of eight subjects in the control group regained more than $50 \%$ of the weight lost, versus four of seven in the trained group. The overall regain of BW at 16 months was $64 \%( \pm 26 \%)$ for the whole group $(52 \% \pm 28 \%$ for trained $v$ $74 \% \pm 20 \%$ for control, $t(1,13)=-1.84, P=.09)$. There was no significant correlation between the training hours per week and the regain of $\mathrm{BW}$ at 16 months $(r=.41, P=.13)$.

Changes in FFM $(\triangle F F M)$ and FM $(\triangle F M)$ are shown in Fig 3 for the treatment period ( 0 to 4 months) and the intervention period (4 to 16 months). The regain of FM during the intervention period was significantly lower for the trained group versus the control group. At 16 months, the regain of FM was $4.8 \pm 1.9 \mathrm{~kg}$, corresponding to a $61 \% \pm 24 \%$ regain of $\mathrm{FM}$, for trained subjects, compared with $9.0 \pm 3.3 \mathrm{~kg}$, corresponding to a $92 \% \pm 32 \%$ regain of FM, for the controls $(P=.01)$.

Table 1. Baseline Characteristics of 15 Male Subjects

\begin{tabular}{llll}
\hline \multicolumn{1}{c}{ Characteristic } & Trained $(\mathrm{n}=7)$ & Control $(\mathrm{n}=8)$ & $P$ \\
\hline Age $(\mathrm{yr})$ & $38.0 \pm 3.9$ & $36.6 \pm 6.3$ & NS \\
BW $(\mathrm{kg})$ & $93.1 \pm 14.5$ & $99.5 \pm 12.9$ & NS \\
Height $(\mathrm{m})$ & $1.76 \pm 0.07$ & $1.77 \pm 0.13$ & NS \\
BMI $\left(\mathrm{kg} \cdot \mathrm{m}^{-2}\right)$ & $29.8 \pm 3.0$ & $31.8 \pm 2.3$ & NS \\
WHR & $0.95 \pm 0.04$ & $0.96 \pm 0.04$ & NS \\
Sagittal diameter $(\mathrm{cm})$ & $22.7 \pm 2.2$ & $24.8 \pm 2.2$ & NS \\
Body fat $(\%)$ & $28.0 \pm 3.4$ & $31.0 \pm 3.0$ & NS \\
\hline
\end{tabular}

NOTE. No statistically significant differences were found in baseline characteristics between the groups.

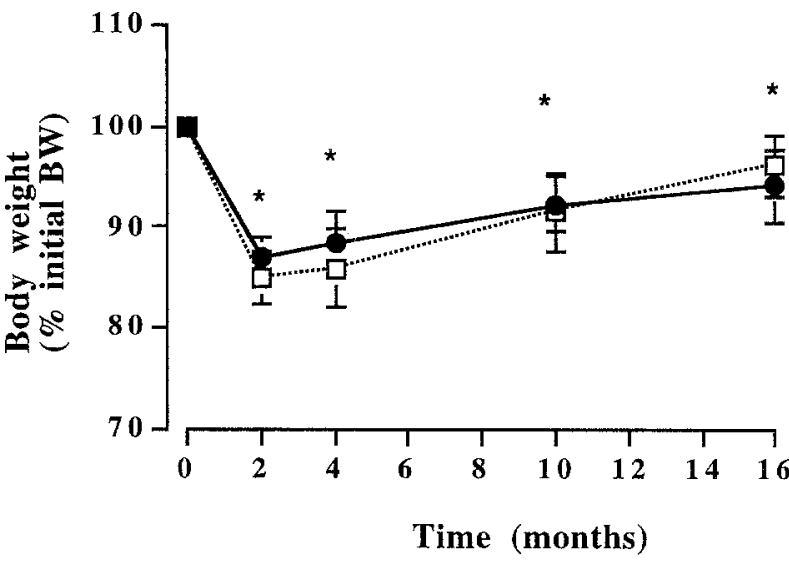

Fig 2. Changes in relative $B W$ expressed as a percentage of the initial value. The mean $\pm S D$ are presented at different time points measured for the trained group (O) and control group ( $\square$ ). *Significant differences $v$ baseline BW for both groups.

\section{Physical Fitness}

Results of the maximal performance tests are presented in Table 2. At 4 months, comparable increases in Wmax and $V$ ${ }_{\mathrm{O}_{2}} \max$ were measured for both groups. The increase in physical fitness at 4 months was significantly higher compared with baseline for both groups $(34 \%$ and $41 \%$ increase for Wmax $\cdot \mathrm{kg}^{-1} \mathrm{BW}$ and $30 \%$ and $36 \%$ for $\dot{\mathrm{VO}}_{2} \max \cdot \mathrm{kg}^{-1} \mathrm{BW}$ for trained $v$ control, respectively). A significantly higher $\mathrm{Wmax}$ was found at 10 and 16 months for the trained group compared with the control group. $\dot{\mathrm{V}}_{2} \max$ was also higher at 10 months $(P<.05)$ and at 16 months $(P=.07)$ for the trained group. Changes in Wmax and $\dot{\mathrm{V}}_{2}$ max are presented as a percentage of baseline and as a percentage of performance at 4 months in Fig 4. During the intervention period ( 4 to 16 months), the trained group maintained the increased level of physical fitness, whereas the control group showed a poorer performance at 16 months compared with 4 months. The difference in Wmax at 10 and 16 months was significant between groups.

\section{Cardiovascular Risk Factors}

CVD parameters such as blood pressure and blood cholesterol did not differ between the groups as a consequence of

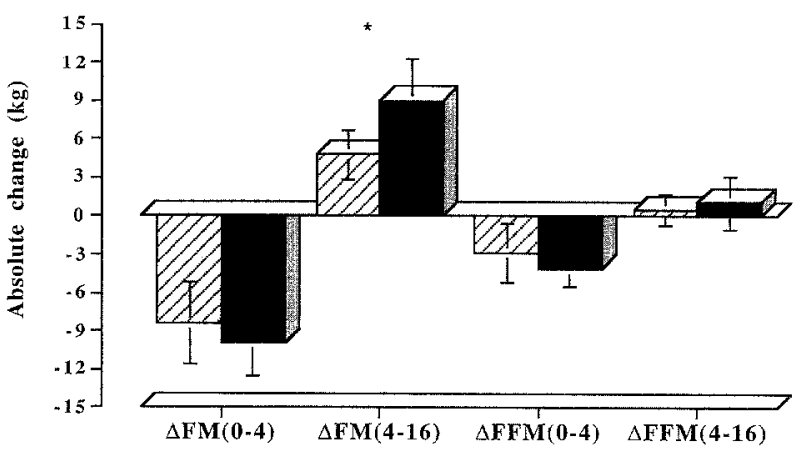

Fig 3. Changes in FFM and FM during the treatment period 10 to 4 months) and during the intervention period (4 to 16 months) for the trained group $(\mathbb{Z})$ and control group $(G)$. 
Table 2. Physical Fitness at Different Time Points

\begin{tabular}{|c|c|c|c|c|c|}
\hline \multirow[b]{2}{*}{ Parameter } & \multicolumn{5}{|c|}{ Months } \\
\hline & 0 & 2 & 4 & 10 & 16 \\
\hline$W \max (W \cdot \operatorname{kg~BW})$ & & & & . & \\
\hline Control & $2.6 \pm 0.2$ & $3.1 \pm 0.3$ & $3.7 \pm 0.4$ & $3.2 \pm 0.2$ & $2.9 \pm 0.2$ \\
\hline \multicolumn{6}{|c|}{$\dot{\mathrm{V}}_{2} \max \left(\mathrm{mL} \cdot \mathrm{min}^{-1} \cdot \mathrm{kg} \mathrm{BW}\right)$} \\
\hline Trained & $32.7 \pm 3$ & $40.8 \pm 5$ & $42.6 \pm 3$ & $39.2 \pm 4^{*}$ & $39.0 \pm 4 \dagger$ \\
\hline
\end{tabular}

NOTE. Absolute data for $W \max$ and $\dot{V}_{2}$ max are shown (mean $\pm S D$ ).

${ }^{*} P<.05$ between groups.

$\dagger P=.07$.

exercise training. However, due to the treatment, systolic and diastolic blood pressure decreased significantly. Diastolic blood pressure decreased, on average, from $95.3 \pm 10.1 \mathrm{~mm} \mathrm{Hg}$ to $87.4 \pm 9.3 \mathrm{~mm} \mathrm{Hg}$ at 4 months. Diastolic blood pressure was still decreased at 16 months for both groups $(88.2 \pm 9.4 \mathrm{~mm}$ $\mathrm{Hg}$ ). Systolic blood pressure was significantly decreased at 4 months $(132.0 \pm 12.8 v 125.5 \pm 13.7 \mathrm{~mm} \mathrm{Hg})$. At 16 months, systolic blood pressure returned to baseline values $(130.1 \pm 13.0$ $\mathrm{mm} \mathrm{Hg}$ ).

Baseline cholesterol data for the two groups are shown in Table 3. Significant changes over time were found for all cholesterol fractions with the VLED program, but not as a consequence of the training intervention. Over time, cholesterol levels returned to the baseline value in both groups. Because of initial differences in cholesterol levels between the groups, interpretation of the data is difficult.

Body fat distribution (abdominal or gluteal) was investigated by examination of the waist circumference, WHR, and sagittal diameter. The amount of regain in the parameters was significantly negatively correlated with the amount of weekly training hours performed ( $\Delta$ waist, $r=-.57, P=.03 ; \Delta \mathrm{WHR}, r=-.48$, $P=.07 ; \Delta$ sagittal diameter, $r=-.55, P=.03$ ).

$R M R$

With respect to the RMR, no differences were found as a result of exercise training. Both groups showed nonsignificantly different RMRs at 16 months versus RMRs measured before the study $\left(87 \pm 7\right.$ and $88 \pm 6 \mathrm{~kJ} \cdot \mathrm{min}^{-1} \cdot \mathrm{FFM}^{-1}$ for trained $v$ $90 \pm 12$ and $91 \pm 10 \mathrm{~kJ} \cdot \mathrm{min}^{-1} \cdot \mathrm{FFM}^{-1}$ for control at the start and end of the study, respectively).

\section{DISCUSSION}

\section{Regain of $B W$ and $F M$}

The major finding of this study is that exercise training did not result in significantly better weight maintenance compared with the control conditions. However, the regain of FM was significantly lower in the trained group (exercise three to four times per week for $\geq 1$ hour at moderate intensity). The results indicate that the smaller the regain of FM, the greater the number of training hours. This finding illustrates that exercise seems to have a weight-controlling aspect, as found in studies analyzing the success factor for long-term weight maintenance. ${ }^{24-26}$ This was also found in a long-term study by van Dale et al. ${ }^{27}$ Long-term weight maintenance was only found in a group of subjects who started to exercise after the diet intervention; no regain of FM was found in their exercise group. The study by van Dale et $\mathrm{al}^{27}$ and the review by Stefanick ${ }^{28}$ on the weight-controlling aspect of exercise stress that exercise is effective for reducing weight regain long-term, contrary to our findings. An additional energy expenditure of $1,500 \mathrm{kcal} / \mathrm{wk}$, equal to 3 to 4 hours of moderate-intensity exercise (cycling and

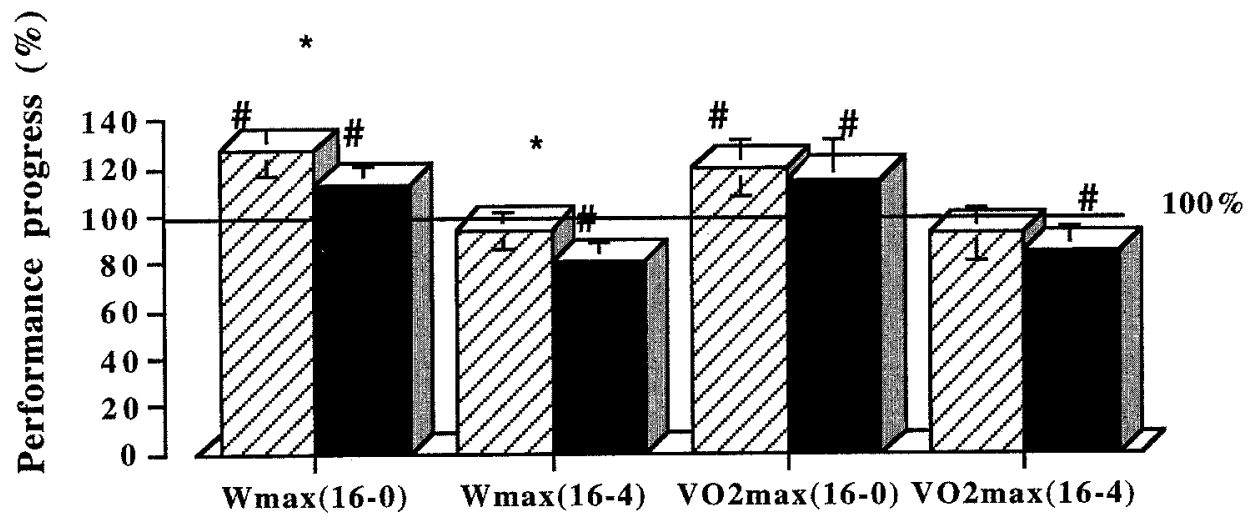

Changes in physical fitness

Fig 4. Wmax and $\mathrm{VO}_{2}$ max at 16 months as a percentage of performance at 0 months (start of study) or at 4 months: trained group ( group (G). *Significant differences between the 2 groups. \#Significant difference $v 100 \%$. 
Table 3. Cholesterol Data at Different Time Points

\begin{tabular}{lccc}
\hline & \multicolumn{3}{c}{ Months } \\
\cline { 2 - 3 } Parameter & 0 & 4 & 16 \\
\hline $\begin{array}{c}\text { Total cholesterol } \\
\quad\left(\mathrm{mmol} \cdot \mathrm{L}^{-1}\right)\end{array}$ & & & \\
$\mathrm{T}$ & $6.9 \pm 1.9 \dagger$ & $6.0 \pm 1.0 \dagger$ & $6.3 \pm 1.3$ \\
$\mathrm{C}$ & $5.0 \pm 1.4$ & $4.7 \pm 1.6$ & $5.1 \pm 1.4$ \\
$\mathrm{HDL}\left(\mathrm{mmol} \cdot \mathrm{L}^{-1}\right)$ & & & \\
$\mathrm{T}$ & $1.1 \pm 0.2$ & $1.3 \pm 0.2$ & $1.2 \pm 0.2 \dagger$ \\
$\mathrm{C}$ & $1.0 \pm 0.3$ & $1.2 \pm 0.4$ & $1.0 \pm 0.2$ \\
$\mathrm{LDL}\left(\mathrm{mmol} \cdot \mathrm{L}^{-1}\right)$ & & & \\
$\mathrm{T}$ & $4.7 \pm 1.6^{*}$ & $4.1 \pm 1.0^{*}$ & $4.4 \pm 1.2^{*}$ \\
$\mathrm{C}$ & $2.9 \pm 1.1$ & $2.8 \pm 1.1$ & $3.1 \pm 0.9$ \\
Triglycerides & & & \\
$\quad\left(\mathrm{mmol} \cdot \mathrm{L}^{-1}\right)$ & & & \\
$\mathrm{T}$ & $1.6 \pm 0.9$ & $0.8 \pm 0.3$ & $1.1 \pm 0.5$ \\
$\mathrm{C}$ & $1.7 \pm 0.5$ & $1.0 \pm 0.3$ & $1.6 \pm 0.6$ \\
Apo A1 $\left(\mathrm{mg} \cdot \mathrm{dL}{ }^{-1}\right)$ & & & \\
$T$ & $126.8 \pm 19.4$ & $142.7 \pm 19.0$ & $131.0 \pm 17.7$ \\
$\mathrm{C}$ & $114.6 \pm 28.3$ & $126.3 \pm 35.2$ & $119.3 \pm 20.2$ \\
Apo B $\left(\mathrm{mg} \cdot \mathrm{dL}^{-1}\right)$ & & & \\
$\mathrm{T}$ & $104.2 \pm 28.5^{*}$ & $90.0 \pm 20.0 \dagger$ & $100.2 \pm 25.0 \dagger$ \\
$\mathrm{C}$ & $74.3 \pm 22.8$ & $66.4 \pm 21.9$ & $78.4 \pm 20.7$ \\
\hline
\end{tabular}

NOTE. Results are the mean \pm SD.

Abbreviations: $T$, trained; $C$, control.

${ }^{*} P<.05$ between groups.

tP<.1 between groups.

running), should be sufficient for effective weight maintenance. ${ }^{26,29}$ However, in some studies, a maintenance program was used in addition to exercise in which subjects were informed weekly in group settings about nutrition, eating behavior, and tips for low-fat cooking. ${ }^{26,29}$ In a study by Ewbank et al, ${ }^{25}$ subjects were weighed 2 years post-VLED when they were unrestricted by diet. When grouped by the amount of exercise performed weekly, their 2-year regain levels corresponded to our results $(72 \%$, compared with $63 \%$, on average, in this study). Especially in the group of subjects that performed exercise five times per week (total, $\pm 2,300 \mathrm{kcal}$ ), even less regain was found $(24 \%)$.

Although different reports have described the mechanisms for the weight-controlling aspects of exercise, ${ }^{12}$ it still remains striking that the exercise group also regained FM. It seems difficult to maintain the decreased BW achieved after the 4-month treatment. The above-mentioned studies stress the importance of a high frequency of exercise weekly and participation in group sessions (high compliance and strenuous exercise). The explanations for the increase in BW and FM in our study despite the regular intense exercise could be several. The daily energy intake may be increasing more than the energy expenditure, as already found for females. ${ }^{30}$ In our study, the frequency of training may be too low for weight maintenance; different studies report that activities should be incorporated into life on a daily basis. ${ }^{11,24-26,31}$ Another possible explanation for the $\mathrm{BW}$ regain in this study is that insufficient oxidation of fat led to a positive lipid balance when fat intake was high, resulting in long-term BW gain. ${ }^{10}$ Tremblay and Buemann ${ }^{10}$ further suggested that the beneficial effects of exercise cannot be maintained on a long-term basis if the new exercise and food habits are not incorporated into the life-style of the individual.
Long-term effects of exercise training seem small and are rapidly suppressed with cessation of training. ${ }^{11}$ The small number of subjects participating in this study can further explain the fact that the differences found were not significant. A calculation of the power at $80 \%$ (assumptions: a difference in weight regain of $20 \%$, a standard deviation of $15 \%$, and a dropout rate of $20 \%$ ) showed that a difference in BW regain of $20 \%$ between the active and control groups could be detected. However, based on our results, a calculation afterward showed a power of only $55 \%$.

\section{Physical Fitness}

In this study, we found an increase in $\dot{\mathrm{V}}_{2} \max$ of approximately $33 \%$ for both groups after 4 months of training. The trained group maintained this level of $\dot{\mathrm{V}}_{2} \max$ at 16 months, in contrast to the control group. The increase in $\mathrm{VO}_{2} \max$ is comparable to the increases in oxygen uptake found by Katzel et al. ${ }^{14}$ In their study, subjects were asked to cycle three times per week for 45 minutes at $70 \%$ to $80 \%$ of the heart rate reserve for 9 months. ${ }^{14}$ The increased $W \max$ in the trained group further illustrates that endurance training resulted in better physical fitness compared with the control groups. The relatively high $\mathrm{V}$ ${ }_{\mathrm{O}_{2}}$ max at 16 months for the control group indicates that changes caused by the 4-month training period were still at a higher level compared with the start of the study. It is possible that adaptation to exercise training occurred and was partially maintained during the intervention period even with no specific training program. The significantly increased $\mathrm{VO}_{2} \max$ found in this study for both groups has been reported to be positively correlated with higher insulin sensitivity. This suggests again that training had beneficial health effects. ${ }^{13,32}$

\section{Cardiovascular Risk Factors}

In the present study, no differences in blood pressure, cholesterol, and cardiovascular risk factors were found as a result of the training program. Blood pressure and cholesterol data were reduced after the VLED treatment, but returned to baseline values during the long-term intervention, as found previously. ${ }^{33}$ Another important risk factor for CVD is the waist circumference (or WHR) or the sagittal diameter. ${ }^{34}$ In several studies, the relation of abdominal fat distribution to exercise was reported..$^{10,11,15,16,35}$ In this study, we found negative correlations between the weekly amount of training hours and waist circumference and also for sagittal diameter, suggesting that exercise effectively prevented the regain of upper-body fat. The changes in waist circumference, WHR, and sagittal diameter were significantly higher for the control group at 16 months. In men, upper-body obesity is more common than in women, and a preferential mobilization of abdominal fat with exercise has been found. ${ }^{11}$ Björntorp ${ }^{36}$ has already stated in different studies that abdominal obesity, with hypertrophic cells, can mobilize fat easier than peripheral fat sites. $\beta$-Adrenergic stimulation that takes place during exercise increases fat mobilization in the abdomen effectively. Furthermore, reducing the filling state of fat cells in the abdomen reduces insulin resistance. Insulin resistance is another important risk factor for CVD. ${ }^{35,36}$ In this study, the results indicate a decrease in abdominal fat in the trained group and an improvement of the risk factor profile for these subjects. 


\section{$R M R$}

In this study, no changes in RMR were found between the two groups as a consequence of the exercise training. The decrease in RMR after the VLED in this study is a common phenomenon frequently reported. ${ }^{37}$ At the end of the study, the RMR was similar for both groups, as at the start of the study. The hypothesized effect of exercise on the RMR, ie, an increase in the RMR, as found before, ${ }^{38,39}$ could contribute to BW loss or BW maintenance. However, a decrease in RMR also has been found as a consequence of endurance training. ${ }^{40-42} \mathrm{~A}$ reduced RMR has been found to correlate with $\mathrm{BW}$ gain. ${ }^{11,43}$ The regain of BW and FM found in the present study could therefore be partly explained by the decreased RMR after the diet intervention. However, at the end of the study, no differences between groups and no differences with the initial RMR were found, suggesting that in the long-term other factors affected weight gain, too. Therefore, the effect of training on the RMR is still unclear.

\section{Conclusion}

In this study, we found that although the regain of BW was not significantly different in the groups, the trained group had less regain of FM. Significantly less regain of waist circumference, WHR, and sagittal diameter was found when more training hours per week were performed. Higher levels of physical fitness and less regain of FM and abdominal fat as found in the trained group are positive factors related to lower risk factors for CVD. However, the regain of FM in the trained group suggests that maintenance of fat loss is extremely difficult, even with a relatively intensive exercise program.

\section{REFERENCES}

1. Hubert HB, Feinleib M, McNamara PM, et al: Obesity as an independent risk factor for cardiovascular disease: A 26-year follow-up of participants in the Framingham Heart Study. Circulation 67:968-977, 1983

2. Stamler R, Stamler J, Riedlinger WF, et al: Weight and blood pressure. Findings in hypertension screening of 1 million Americans. JAMA 240:1607-1610, 1978

3. Kromhout D: Body weight, diet, and serum cholesterol in 871 middle-aged men during 10 years of follow-up (the Zutphen Study). Am J Clin Nutr 38:591-598, 1983

4. Kuczmarski RJ, Flegal KM, Campbell SM, et al: Increasing prevalence of overweight among US adults. The National Health and Nutrition Examination Surveys, 1960 to 1991. JAMA 272:205-211, 1994

5. Seidell JC: Obesity in Europe. Obes Res 3:89s-93s, 1995 (suppl 2)

6. Sjöström L: Can the relapsing patient be identified?, in Björntorp P, Cairella M, Howard AN (eds): Recent Advances in Obesity Research: III. Proceedings of the Third International Congress on Obesity. London, UK, Libbey, 1974, pp 85-93

7. Garner DM, Wooley SC: Confronting the failure of behavioral and dietary treatments for obesity. Clin Psychol Rev 11:729-780, 1991

8. Rössner S: Factors determining the long-term outcome of obesity treatment, in Björntorp P, Brodoff BN (eds): Obesity. Philadelphia, PA, Lippincott, 1992, pp 712-719

9. Flatt JP: Dietary fat, carbohydrate balance and weight maintenance. Ann NY Acad Sci 683:122-140, 1993

10. Tremblay A, Buemann B: Exercise-training, macronutrient balance and body weight control. Int J Obes 19:79-86, 1995

11. Bouchard C, Deprés J-P, Tremblay A: Exercise and obesity. Obes Res 1:133-147, 1993

12. Saris WHM: Physical activity and body weight regulation, in Bouchard C, Bray GA (eds): Regulation of Body Weight: Biological and Behavioral Mechanisms. New York, NY, Wiley, 1996, pp 135-148

13. Barnard RJ, Wen SJ: Exercise and diet in the prevention and control of the metabolic syndrome. Sports Med 18:218-228, 1994

14. Katzel LI, Bleecker ER, Colman EG, et al: Effects of weight loss vs aerobic exercise training on risk factors for coronary disease in healthy, obese, middle-aged and older men. JAMA 274:1915-1921, 1995

15. Buemann B, Tremblay A: Effects of exercise training on abdominal obesity and related metabolic complications. Sports Med 21:191-212, 1996

16. Weidner MD, Gavigan KE, Tyndall GL, et al: Which anthropometric indices of regional adiposity are related to the insulin resistance of aging? Int J Obes 19:325-330, 1995
17. Blair SN, Kohl HW, Paffenberger RS Jr, et al: Physical fitness and all-cause mortality; a prospective study of healthy men and women. JAMA 262:2395-2401, 1989

18. Kushner RF, Racette SB, Neil K, et al: Measurement of physical activity among black and white obese women. Obes Res 3:S261-S265, 1995 (suppl 2)

19. Pronk NP, Wing RR: Physical activity and long-term maintenance of weight loss. Obes Res 2:587-599, 1994 (review)

20. Weir JB de V: New methods for calculating metabolic rate with special reference to protein metabolism. J Physiol 109:1-9, 1949

21. Muls E, Kempen KPG, Vansant G, et al: The effects of weight loss and apolipoprotein $\mathrm{E}$ polymorphism on serum lipids, apolipoproteins A-I and B, and lipoprotein(a). Int J Obes 17:711-716, 1993

22. Schoeller DA, van Santen E, Peterson DW, et al: Total body water measurement in humans with ${ }^{18} \mathrm{O}$ and ${ }^{2} \mathrm{H}$ labeled water. Am J Clin Nutr 33:2686-2693, 1980

23. van Marken Lichtenbelt WD, Westerterp KR, Wouters L: Deuterium dilution as a method for determining total body water: Effect of test protocol and sampling time. Br J Nutr 72:491-497, 1994

24. Harris JK, French SA, Jeffery RW, et al: Dietary and physical activity correlates of long-term weight loss. Obes Res 2:307-313, 1994

25. Ewbank PP, Darga LL, Lucas CP: Physical activity as a predictor of weight maintenance in previously obese subjects. Obes Res 3:257263,1995

26. Hartman WM, Stroud M, Sweet DM, et al: Long-term maintenance of weight loss following supplemented fasting. Int J Eat Disord 14:87-93, 1993

27. van Dale D, Saris WHM, ten Hoor F: Weight maintenance and resting metabolic rate $18-40$ months after a diet/exercise treatment. Int J Obes $14: 347-359,1990$

28. Stefanick ML: Exercise and weight control. Exerc Sport Sci Rev 21:363-396, 1993

29. Pavlou KN, Whatley JE, Jannace PW, et al: Physical activity as a supplement to a weight-loss dietary regimen. Am J Clin Nutr 49:11101114,1989

30. Westerterp KR, Meijer GAL, Janssen EME, et al: Long-term effect of physical activity on energy balance and body composition. Br J Nutr 68:21-30, 1992

31. Davidson RCR, Grant S: Is walking sufficient exercise for health? Sports Med 16:369-373, 1993

32. Clausen JO, Borch-Johnsen K, Ibsen H, et al: Insulin sensitivity index, acute insulin response, and glucose effectiveness in a populationbased sample of 380 young healthy caucasians. Analysis of the impact of gender, body fat, physical fitness, and life-style factors. J Clin Invest 98:1195-1209, 1996 
33. Saris WHM, Koenders MC, Pannemans DLE, et al: Outcome of a multicenter outpatient weight-management program including verylow calorie diet and exercise. Am J Clin Nutr 56:294S-296S, 1992 (suppl)

34. Hodgson JM, Wahlqvist ML, Balazs NDH, et al: Coronary athero-sclerosis in relation to body fatness and its distribution. Int $\mathrm{J}$ Obes 18:41-46, 1994

35. Krotkiewski M, Björntorp P: Muscle tissue in obesity with different distribution of adipose tissue. Effects of physical training. Int $J$ Obes 10:331-341, 1986

36. Björntorp P: Physical training in the treatment of obesity. Int $\mathbf{J}$ Obes 2:149-156, 1978

37. Shah M, Jeffery RW: Is obesity due to overeating and inactivity or to a defective metabolic rate? A review. Ann Behav Med 13:73-81, 1991

38. Tremblay A, Nadeau A, Fourier G, et al: Effect of a three-day interruption of exercise training on resting metabolic rate and glucose- induced thermogenesis in trained individuals. Int J Obes 12:163-168, 1988

39. Westerterp KR, Saris WHM, Soeters PB, et al: Physical activity and resting metabolic rate. Med Sci Sports Exerc 23:166-170, 1991

40. Phinney SD, LaGrange BM, O'Connell $\mathrm{M}$, et al: Effects of aerobic exercise on energy expenditure and nitrogen balance during very low calorie dieting. Metabolism 37:758-765, 1988

41. Heymsfield SB, Casper K, Hearn J, et al: Rate of weight loss during underfeeding: Relation to level of physical activity. Metabolism $38: 215-223,1989$

42. Tremblay A, Poehlman ET, Deprés J-P, et al: Endurance training with constant energy intake in identical twins: Changes over time in energy expenditure and related hormones. Metabolism 46:499-503, 1997

43. Ravussin E, Lillioja S, Knowler WC, et al: Reduced rate of energy expenditure as a risk factor for body weight gain. $\mathrm{N}$ Engl J Med $318: 467-472,1988$ 